\title{
SUPREMO TRIBUNAL FEDERAL E A PRESUNÇÃO DE INOCÊNCIA: ATIVISMO, CONTEXTO E AÇÃO ESTRATÉGICA
}

\section{FEDERAL SUPREME COURT AND THE PRESUMPTION OF INNOCENCE: ACTIVISM, CONTEXT, AND STRATEGIC ACTION}

\author{
FABIANA ALVES RODRIGUES ${ }^{1}$ \\ ROGÉRIO BASTOS ARANTES ${ }^{2}$
}

\begin{abstract}
RESUMO: Este artigo explora o julgamento do Supremo Tribunal Federal (STF) que reverteu seu posicionamento anterior sobre a presunção de inocência, passando a admitir a execução da pena a partir da decisão condenatória em segunda instância. Como explicar essa mudança de interpretação constitucional? Procedeu-se à análise qualitativa dos votos e julgamentos, orientada pelo exame i) do modo pelo qual se operou o poder de agenda da Corte; ii) da coerência (ou sua falta) dos argumentos expostos nos votos dos ministros; e iii) de possíveis efeitos da decisão sobre os rumos da operação Lava Jato. A análise permite concluir que a ratio decidendi da Corte passou de questões técnico-jurídicas para a busca de efetividade da jurisdição penal. Não sem agregar elementos contextuais na explicação, o artigo sugere que a ação do STF visou remodelar o arranjo institucional da justiça criminal, sob o impacto da operação Lava Jato, reforçando especialmente o estímulo à celebração de colaborações premiadas, diante do risco mais iminente de encarceramento decorrente da nova jurisprudência. A ação estratégica da Corte leva a um debate que vai além da judicialização da política e envolve o ativismo judicial na remodelagem de regras institucionais, no campo do combate à criminalidade de colarinho branco e da classe política.
\end{abstract}

Palavras-Chave: Ratio decidendi; Supremo Tribunal Federal; “Operação Lava Jato", ativismo judicial, comportamento estratégico.

\footnotetext{
${ }^{1}$ Mestra (2019) e Doutoranda em Ciência Política (em andamento) pela Universidade de São Paulo. Contato: fabi.far@gmail.com.

2 Professor do Departamento de Ciência Política da Universidade de São Paulo. Contato: rarantes@usp.br.
} 
ABSTRACT: This article explores the ruling in which the Federal Supreme Court (STF) reversed its previous position on the presumption of innocence, allowing criminal convictions to be provisionally enforced after confirmation by a trial court. How to explain this change of constitutional interpretation? In this paper, we perform a qualitative analysis of the opinions, focusing on i) the way by which the Court's agenda-setting power was employed; ii ) the consistency (or lack thereof) of the arguments presented in Justices' opinions, and iii) the decision's possible effects on the direction of the Lava Jato operation. We observe that the Court's ratio decidendi distanced itself from technical-legal issues and focused on concerns with the effectiveness of the criminal justice system. By incorporating contextual elements to the explanation, the article suggests that Supreme Court aimed to reshape the institutional arrangements of the criminal justice system, under the impact of the Lava Jato operation. In particular, the Court strengthened defendants' incentives to celebrate plea bargain agreements with prosecutors, as the new interpretation increased the risk of their actual incarceration. The Court's strategic action leads to a debate beyond the judicialization of politics, involving judicial activism in the reshaping of institutional rules in the area of white collar crimes and crimes committed by politicians.

KeYWORDS: Ratio decidendi; Federal Supreme Court; "Operation Lava Jato", judicial activism, strategic behavior.

\section{INTRODUÇÃO}

A ampliação da autoridade do Poder Judiciário é fenômeno que vem sendo observado em diversos países e de forma muito especial no Brasil, no que parte considerável da literatura designa como judicialização da política (TATE; VALLINDER, 1995). Retomando os fundamentos deste debate teórico, esse artigo pretende analisar e contextualizar os julgamentos dos habeas corpus $\mathrm{n}^{\text {os }} 84.078-7$ (2008) e 126.292 (2016), nos quais o Supremo Tribunal Federal fixou e depois modificou posicionamento sobre a presunção de inocência, passando da afirmação constitucional do princípio no primeiro caso, à admissão da execução provisória da pena depois da condenação em segunda instância (ainda que sujeito a recurso perante o Superior Tribunal de Justiça ou Supremo Tribunal Federal) no segundo HC.

Por que a Corte Constitucional modificou esse entendimento em espaço de tempo de apenas sete anos? As razões dessa mudança podem ser extraídas da leitura dos votos proferidos pelos ministros? É possível identificar fatores externos, não explícitos nos votos, que tenham contribuído para a mudança de interpretação? Afinal, o que este caso nos dá a conhecer sobre o processo decisório na Corte e seu impacto sobre o sistema institucional mais amplo? 
Esse artigo pretende explorar tais questões com o objetivo de mapear o contexto da mudança, conectando a ratio decidendi dos julgados com seus esperados efeitos sobre a dinâmica institucional envolvendo o sistema de justiça criminal e a atuação de órgãos no combate à corrupção da classe política.

A análise qualitativa dos julgados aponta que a mudança de posicionamento da Corte não decorreu simplesmente da alteração de sua composição ao longo do período, pois houve significativa alteração na natureza dos argumentos expostos como razão de decidir, que passaram de questões técnico-jurídicas a argumentos de viés mais pragmático e focado na eficiência da jurisdição penal.

$\mathrm{O}$ argumento central do artigo é que as razões expostas nos votos dos ministros, as peculiaridades dos julgamentos, o exercício do poder de agenda, a mobilização das estatísticas processuais do STF e a influência da operação Lava Jato formam um quebra-cabeça que só se torna inteligível mediante a seguinte interpretação: a Corte agiu de forma estratégica, no contexto das operações de combate à corrupção, de modo a assegurar a efetividade das ações desencadeadas a partir da Justiça Criminal de primeiro grau, especialmente e de modo exemplar a Operação Lava Jato.

Mais especificamente, argumentamos que a atividade jurisdicional criminal tem feito, na última década, uso cada vez mais frequente do encarceramento e utilizado seu risco iminente como estratégia para obtenção de colaborações premiadas, ferramenta que se tornou decisiva na produção de provas e na efetividade processual das grandes operações que envolvem a classe política e detentores do poder econômico.

De fato, na perspectiva deste artigo, a decisão do STF sobre o alcance da presunção de inocência ganha grande importância, pois é possível postular que quanto mais iminente o risco de encarceramento, maior será a conveniência do uso da colaboração premiada como forma de diminuição da pena ou obtenção de perdão judicial, o que, sob a ótica da acusação, aumenta a eficácia na produção de provas e identificação de outros autores de crimes.

A análise de tais elementos sugere que a mudança de posicionamento pode ser identificada como postura ativista da Corte, algo que desafia o debate sobre a judicialização da política, em geral centrado apenas na ampliação da autoridade do Poder Judiciário em detrimento dos demais poderes, como mera decorrência do desenho institucional. Assumindo papel ativo na busca pela efetividade do sistema de justiça criminal, o STF agiu de modo estratégico ao reformular a regra em torno da execução provisória da pena. A isto denominamos de ativismo judicial voltado à modelagem institucional, algo que pode ser observado em outras tantas decisões do tribunal. 


\section{O JUDICIALIZAÇÃO DA POLÍTICA, ATIVISMO JUDICIAL E AÇÃO ESTRATÉGICA}

Um volume expressivo da literatura sobre judicialização da política parte do conceito elaborado por Torbjörn Vallinder e das condições comportamentais e institucionais que promovem a judicialização elencadas por C. Neal Tate. Segundo a perspectiva inaugurada por estes autores e largamente incorporada à literatura nacional, a judicialização da política abrange dois aspectos: a expansão da esfera de atuação dos juízes e tribunais em detrimento dos políticos e administradores públicos e a expansão dos métodos decisórios judiciais para outras esferas de atuação do Estado (VALLINDER, 1995).

Essas duas formas de judicialização da política podem não se desenvolver conjuntamente, mas elas emergem sob certas condições comuns, que foram sintetizadas por aqueles autores: presença de governo democrático, separação de poderes, política de direitos (carta de direitos), uso do Tribunal por grupos de interesses e para exercício de oposição, instituições majoritárias não efetivas ou percepção de que as instituições responsáveis por políticas públicas estão imobilizadas, além da delegação de autoridade para tomada de decisão das instituições majoritárias para as judiciais.

O regime político brasileiro reúne todas as condições listadas por Tate e Vallinder, com destaque para aspectos do arranjo institucional que muito favorecem a judicialização da política no país: separação rigorosa de poderes, federalismo, uma Constituição extensa e detalhada e um sistema de controle constitucional das leis que atribui aos juízes e especialmente ao Supremo Tribunal Federal um papel extremamente relevante no controle dos atos normativos editados pelos Poderes Legislativo e Executivo, nas esferas federal e estadual. Pode-se dizer que a existência de amplas competências e hipóteses de atuação da Justiça no controle da produção normativa, mas também das políticas públicas, representa uma espécie de delegação voluntária de poderes ao Judiciário, ao Ministério Público e a outras instituições deste campo, especialmente quando consideramos o leque de ações disponíveis para a promoção do controle constitucional, o amplo rol de atores legitimados a utilizarem estas ações, além dos poderes de representação extraordinária concedidos ao Ministério Público no controle dos governantes e da administração pública em geral (ARANTES, 2015).

Ademais dessas condições facilitadoras, a judicialização da política pressupõe a presença de outro elemento: que os juízes tenham determinadas atitudes pessoais, valores e preferências políticas, e que decidam que devem participar da elaboração de política pública, o que parte da literatura denomina por ativismo judicial (TATE, 1995).

Este segundo aspecto da formulação de Tate tem sido pouco explorado pelos estudos sobre judicialização da política no Brasil, e por isso voltamos à obra já consagrada destes autores. Um balanço da literatura indicaria que a maior parte 
das análises tem se dedicado ao estudo das dimensões institucionais que propiciam a judicialização da política no país, enquanto o ativismo judicial tem sido comparativamente menos pesquisado. Neste artigo, as condições institucionais compõem a análise, mas o caso que analisamos permite examinar essa outra dimensão do fenômeno, isto é, quando atores judiciais se lançam no universo da política e, mais precisamente, alteram regras institucionais de modo a alcançar, estrategicamente, resultados por eles almejados.

Segundo Kmiec (2004), “ativismo judicial” é um conceito carente de definição mais precisa e nos debates político e judicial a expressão apresenta geralmente uma conotação pejorativa, quando não fortemente negativa. Vasculhando a origem do termo, Kmiec encontrou seu primeiro uso sistemático em texto publicado por Schlesinger Jr. no magazine Fortune, em 1947. Examinando o comportamento dos nove juízes da Suprema Corte americana e procurando identificar alianças e divisões entre eles, Schlesinger Jr. os separou em dois grupos bastante nítidos, os "Judicial activists" (integrado por 4 justices) e os "Champions of Self Restraint" (integrado por 3 justices), com outros dois juízes ocupando posições intermediárias entre eles (apud KMIEC, 2004, p. 1446). Kmiec faz então um vasto inventário dos usos da noção entre acadêmicos, juízes e políticos. Ao final, sintetiza cinco significados, na expectativa de adensar o conceito e seus usos possíveis na pesquisa empírica.

Um primeiro significado de ativismo judicial é aquele que descreve decisões de juízes que derrubam ações de outros poderes, mesmo quando essas são indiscutivelmente constitucionais. O problema dessa definição, obviamente, é saber com quem está a razão constitucional, mas os autores que investiram nessa direção alegam que mesmo questões constitucionalmente ambíguas não deveriam servir de álibi para a atuação judicial contra decisões políticas. Apenas aquelas situações de flagrante inconstitucionalidade é que permitiriam a correção da lei pelo judiciário. Todas as demais hipóteses incorreriam em ativismo judicial.

Uma segunda definição, tecnicamente mais precisa, é aquela que opõe ativismo e respeito a precedentes. Em direção vertical, decisões de cortes inferiores seriam marcadas por ativismo quando deixam de seguir precedentes da suprema corte; em linha horizontal, haveria ativismo quando a suprema corte deixa de seguir entendimento firmado por ela mesma em casos anteriores semelhantes (escapando ao principio do stare decisis). ${ }^{3}$ Uma terceira definição é ainda mais sintética: "judicial

\footnotetext{
${ }^{3}$ Ainda com relação a precedentes, Kmiec (2004, p. 1469) considera que o respeito a eles pode variar de acordo com o tipo de norma - se constitutional, statutory ou common law. Paradoxalmente, os dois últimos seriam mais dificeis de desrespeitar, pois estão assentados em manifestações claras de legisladores e juízes de primeiro grau. Já o precedente assentado na constituição deve ser considerado menos rígido por causa da dificuldade de emendar a própria constituição. Explicando melhor, para compensar a dificuldade de emendamento, a corte deve ser menos deferente a precedentes constitucionais para ter a flexibilidade de atualizar o sentido da constituição, dado que por emendamento isto é mais difícil.
} 
legislation" ou "legislate from the bench" abrange decisões de juízes que introduzem norma onde não havia, criando legislação.

Um quarto significado aponta para a questão do método de interpretação constitucional. A ideia é que ativismo judicial ocorre quando juízes recorrem a métodos heterodoxos ou diferentes daqueles comumente aceitos. Kmiec argumenta que hoje essa variedade de metodologias é uma realidade, mas assim mesmo o uso de diferentes métodos, sobretudo quando produzem resultados distintos, pode ensejar de parte a parte a crítica de ativismo judicial. Por fim, o quinto significado diz respeito a julgamentos orientados para resultados. Estes implicariam um motivo pré-existente que faz o julgador afastar-se, inclusive, da correção básica que se pode esperar de um voto sobre a matéria. Há, nessa espécie de ativismo, um "scienter element", isto é, a adoção de um ponto de partida consciente e deliberadamente irregular por parte do julgador, mas que the permitirá chegar ao resultado almejado (KMIEC, 2004, p. 1475).

Os casos que vamos examinar em seguida contêm elementos presentes nessas cinco definições de ativismo judicial. Todavia, antes de passarmos ao seu exame, cabe definir igualmente o uso da expressão "ação estratégica" que fazemos neste artigo. De certo modo, a questão guarda relação com o debate sobre os modelos de explicação do comportamento judicial em supremas cortes, especialmente os denominados como atitudinal e estratégico. ${ }^{4}$ Numa apreciação sumária, o primeiro modelo prediz que juízes constitucionais buscam maximizar suas preferências sinceras por policy, quando decidem, e as condições institucionais de independência nas quais se encontram favorecem esse comportamento. No segundo modelo, tais condições são relativizadas e os juízes são vistos como atores que precisam calibrar suas preferências frente a restrições (internas e externas ao tribunal) ao seu comportamento individual. Há mais continuidade do que ruptura de argumentação na passagem de um modelo a outro. Neste texto, em particular, vamos argumentar que os ministros do STF agiram de acordo com suas preferências a respeito da questão do cumprimento da pena, mas o fizeram de modo estratégico mirando o impacto de suas decisões sobre o sistema de justiça criminal mais amplo.

Também partimos do pressuposto de que o desenho institucional que contribuiu para a chamada "Supremocracia" 5 constitui o pano de fundo dessa ação estratégica, determinada a modificar a posição sobre o princípio da presunção de

\footnotetext{
${ }^{4}$ É vasta a literatura norte-americana sobre tais modelos e mesmo no Brasil muitos trabalhos, especialmente monografias e teses, têm se encarregado de sua disseminação. Para uma boa introdução sobre os fundamentos teóricos e institucionais desses modelos e os desafios para sua transposição ao caso brasileiro, ver Ribeiro e Arguelhes (2013).

${ }^{5}$ Na formulação de Vieira (2008). Para o autor, a constituição de 1988 e as reformas legais e constitucionais que lhe seguiram aumentaram significativamente a autoridade decisória do STF, seja em relação aos demais poderes, seja em relação às instâncias inferiores do Judiciário.
} 
inocência, mesmo sem prévia provocação dos legitimados ao controle de constitucionalidade.

\section{TRÂMITE DOS HABEAS CORPUS}

No que diz respeito especificamente ao STF, a literatura que se ocupa do tribunal costuma tratar o tema da judicialização da política e do ativismo de seus ministros com especial foco nas ações de controle de constitucionalidade (Arantes e Arguelhes, 2019), dando pouca atenção a outros tipos de processos como, por exemplo, o habeas corpus, ação constitucional destinada a afastar a violência ou coação na liberdade de locomoção, por ilegalidade ou abuso de poder.

A despeito de se tratar de procedimento que não permite ampla produção de provas, o habeas corpus viabiliza o reconhecimento de significativo leque de ilegalidades, o que confere à Corte extensos poderes para fixar inclusive novos entendimentos sobre critérios de aplicação da legislação ordinária, como o fez, por exemplo, na parametrização do princípio da insignificância para fins de tipicidade penal (HC84412-0). Também permite o exercício do controle de constitucionalidade, o que ocorreu no julgamento dos dois habeas corpus objetos deste artigo, como veremos a seguir.

A fim de facilitar a leitura, denominaremos o habeas corpus $\mathrm{n}^{\mathbf{0}} 84.078-7$, julgado em 2009, por HC1 e o habeas corpus no 126.292, julgado em 2016, por HC2. Nos dois HCs os ministros discutiram a interpretação do artigo 5, inciso VLII da Constituição Federal ${ }^{6}$. Detalharemos os processos adiante, mas resumidamente, no HC1 o tribunal havia fixado o entendimento de que o réu podia aguardar em liberdade até o trânsito em julgado da sentença, enquanto no HC2 a posição majoritária passou a autorizar a execução provisória da pena após a condenação em segunda instância. Entre um HC e outro, é importante registrar desde início, o Congresso aprovou em 2011 uma importante modificação no Código de Processo Penal (CPP), alterando seu artigo 283 para definir mais claramente as hipóteses de prisão. 7 A nova redação, motivada à época justamente pela preocupação com o encarceramento em massa, fala expressamente sobre a necessidade de sentença transitada em julgado para que se possa proceder à prisão. Assim, a discussão sobre a constitucionalidade do novo artigo 283, de 2011, só poderia aparecer no julgamento do HC2, de 2016, mas como veremos adiante, os ministros praticamente ignoraram a vontade do legislador nessa matéria.

Outras duas observações preliminares são necessárias. Entre o julgamento do HC1 e do HC2 nenhum litigante suscitou a questão constitucional perante o STF

\footnotetext{
${ }^{6}$ LVII - ninguém será considerado culpado até o trânsito em julgado de sentença penal condenatória.

7 Art. 283. Ninguém poderá ser preso senão em flagrante delito ou por ordem escrita e fundamentada da autoridade judiciária competente, em decorrência de sentença condenatória transitada em julgado ou, no curso da investigação ou do processo, em virtude de prisão temporária ou prisão preventiva.
} 
por via do controle difuso de constitucionalidade, na forma de recurso extraordinário (RE) com pedido de repercussão geral. Tal fato sugere que eventual controvérsia sobre o dispositivo constitucional, mesmo que existente no debate jurídico, não foi capaz de alcançar pela via recursal o balcão do STF.

A segunda observação diz respeito ao fato de que, entre o início de vigência do artigo 283 do CPP e o julgamento do HC2, não houve por parte do STF decisões que discutiram a constitucionalidade desse dispositivo legal, seja na forma da repercussão geral em sede de recurso extraordinário, seja por via de ações de controle concentrado, tais como a ação direta de inconstitucionalidade (ADI) ou ação declaratória de constitucionalidade (ADC).

Se considerarmos que o Poder Judiciário se caracteriza pela inércia e deve agir apenas quando provocado, estas observações iniciais são importantes para atestar que, no caso em análise, o STF redefiniu significados constitucionais a partir de expedientes no mínimo improvisados, demonstrando assim um tipo especial de ativismo voltado à modelagem institucional.

A pesquisa de jurisprudência no sítio eletrônico do STF aponta que não houve reconhecimento de repercussão geral, entre o julgamento do $\mathrm{HC1}$ e HC2, sobre a questão da prisão após decisão de segunda instância ${ }^{8}$. Também inexiste reconhecimento de repercussão geral sobre a constitucionalidade do artigo 283 do CPP ou registro de ADI ou ADC que tenham este dispositivo legal indexado?.

Se não houve provocação do STF por meio de ADC, ADI ou RE com repercussão geral, o que motivou a Corte a alterar o posicionamento sobre a amplitude do princípio da presunção de inocência?

Uma constatação importante é que houve mudança de composição do tribunal entre os dois julgamentos. Seis ministros que participaram do julgamento do HC1 não mais integravam a Corte quando o colegiado se reuniu novamente para decidir o tema: Menezes Direito, Joaquim Barbosa, Ellen Gracie, Eros Grau, Ayres Brito, Cezar Peluso. Estes ministros se dividiram no primeiro julgamento, três a favor da

\footnotetext{
8 Levantamento feito para o período de 05/02/09 a 16/02/16, com seleção do dispositivo da constituição (artigo 50, inciso LVII) e resultados sobre "repercussão geral". Os quatro processos com repercussão geral reconhecida não se referem à discussão sobre prisão antes do trânsito em julgado. Disponível em: <http://www.stf.jus.br/portal/jurisprudencia/pesquisarJurisprudencia. asp>. Acesso em: 22 mai. 2017

${ }_{9}^{9}$ Não emergiram quaisquer processos no levantamento feito para o período de 04/07/11 e 16/02/16, seleção do dispositivo legal (artigo 283 do CPP) e resultados sobre "repercussão geral". A pesquisa relativa ao período de 04/07/11 e 16/02/16, com seleção do dispositivo legal (artigo 283 do CPP) e resultados "todos" traz quatro acórdãos, quatro decisões monocráticas e uma decisão da presidência, mas nenhum dos processos se refere a ações de controle concentrado de constitucionalidade (ADC e ADI). As ADCs que hoje repercutem sobre o caso, as de números 43 e 44, foram protocoladas apenas em 19 e 20 de maio de 2016, respectivamente, ou seja, após o julgamento do $\mathrm{HC} 2 \mathrm{e}$, na verdade, como reação à decisão do STF, que contrariou expressamente aquela redação do art. 283 do CPP.
} 
prisão apenas após o trânsito em julgado e três pela prisão a partir da condenação em segunda instância.

Dos seis ministros que ingressaram na Corte e participaram apenas do julgamento do $\mathrm{HC} 2$, cinco manifestaram-se a favor da mudança do posicionamento para estabelecer que a prisão após a condenação em segunda instância não viola o princípio da presunção de inocência. Esse fator, por si só, explicaria a mudança da posição do STF como órgão colegiado, pois o antigo placar de $7 \times 4$ se reverteria em 5 x 6, mesmo sem considerar a mudança de posicionamento do Ministro Gilmar Mendes, que contribuiu apenas para aumentar a diferença de placar na decisão final do HC2 por $4 \times 7$ (tabela 1 ).

Tabela 1 - Votos dos ministros no HC1 (2009) e HC2 (2016)

\begin{tabular}{|l|c|c|}
\hline \multicolumn{1}{|c|}{ MINISTRO } & HC1 (2009) & HC2 (2016) \\
\hline Menezes Direito & S & - \\
\hline Joaquim Barbosa & S & - \\
\hline Ellen Gracie & S & - \\
\hline Cármen Lúcia & S & S \\
\hline Eros Grau & N & - \\
\hline Ayres Britto & $\mathrm{N}$ & - \\
\hline Cezar Peluso & $\mathrm{N}$ & - \\
\hline Marco Aurélio & $\mathrm{N}$ & $\mathrm{N}$ \\
\hline Celso de Mello & $\mathrm{N}$ & $\mathrm{N}$ \\
\hline Lewandowski & $\mathrm{N}$ & $\mathrm{N}$ \\
\hline Gilmar Mendes & $\mathrm{N}$ & $\mathrm{S}$ \\
\hline Teori Zavascki & - & $\mathrm{S}$ \\
\hline Edson Fachin & - & $\mathrm{S}$ \\
\hline Luís Barroso & - & $\mathrm{S}$ \\
\hline Luiz Fux & - & $\mathrm{S}$ \\
\hline Dias Toffoli & - & $\mathrm{S}$ \\
\hline Rosa Weber & - & $\mathrm{N}$ \\
\hline
\end{tabular}

FONTE: Os autores, a partir do sítio eletrônico do STF. S: a favor da prisão após condenação em segunda instância. N: contrário à prisão após condenação em segunda instância

A segunda constatação reside na diferença entre os tempos de tramitação de cada recurso e o controle de agenda, especialmente no segundo caso.

No primeiro habeas corpus, houve concessão de medida liminar em maio de 2004, deliberação da Turma para afetar a matéria ao plenário em novembro de 2004, tendo havido duas sessões plenárias para decidi-la, uma em abril de 2008 e outra 
em fevereiro de 2009. O segundo habeas corpus teve trâmite bem mais célere, com concessão de medida liminar em 5 de fevereiro de 2015 e decisão pelo plenário no dia 17 de fevereiro do ano seguinte (tabela 2).

Tabela 2 - Cronologia e dados dos Habeas corpus

\begin{tabular}{|c|c|c|}
\hline & HC 84.078-7 (HC 1) & HC 126.292 (HC 2) \\
\hline Crime & tentativa de homicídio qualificado & roubo qualificado \\
\hline Tipo & art. $121, \S 22^{\circ}$, I e IV, art. 14, II, CP & art. $157, \S 2^{\circ}$, I e II, CP \\
\hline Pena & 7 anos e 6 meses de reclusão & 5 anos e 4 meses de reclusão \\
\hline Distribuição & 15 de março de 2004 & 15 de janeiro de 2015 \\
\hline Decisão liminar & 12 de maio de 2004 (Min. Jobim) & $\begin{array}{l}5 \text { de fevereiro de } 2015 \text { (Min. } \\
\text { Teori) }\end{array}$ \\
\hline $\begin{array}{l}\text { Afetado } \\
\text { plenário }\end{array}$ & 24 de novembro de 2004 & 15 de dezembro de 2015 \\
\hline Decisão plenário & $\begin{array}{l}9 \text { de abril de } 2008 \text { (vista min. } \\
\text { Direito) }\end{array}$ & - \\
\hline Decisão plenário & 5 de fevereiro de 2009 & 17 de fevereiro de 2016 \\
\hline Publicação & 26 de fevereiro de 2010 & 17 de maio de 2016 \\
\hline $\begin{array}{l}\text { Votos } \\
\text { disponíveis }{ }^{10}\end{array}$ & $\begin{array}{l}\text { Menezes Direito, Joaquim } \\
\text { Barbosa, Ellen Gracie, Eros Grau, } \\
\text { Ayres Britto, Peluso, Marco } \\
\text { Aurélio, Celso de Mello, Gilmar } \\
\text { Mendes, Cármen Lúcia } \\
\text { manifestação em debates. }\end{array}$ & $\begin{array}{l}\text { Cármen Lúcia, Marco Aurélio, } \\
\text { Celso de Mello, Lewandowski, } \\
\text { Mendes, Zavascki, Fachin, Luís } \\
\text { Barroso, Luiz Fux, Rosa Weber } \\
\text { (Toffoli não proferiu voto } \\
\text { escrito). }\end{array}$ \\
\hline
\end{tabular}

FONTE: Os autores, a partir do sítio eletrônico do STF.

Enquanto o HC1 levou quase cinco anos para ser julgado pelo Plenário, o HC2 foi julgado em um ano. É importante observar que o HC 1 levou três anos e quatro meses para ser pautado depois de afetado ao plenário, enquanto o HC 2 levou apenas dois meses. A ministra Rosa Weber declarou-se inclusive surpresa no início do seu voto no HC2: "este habeas corpus não estava previsto com maior antecedência para a pauta de hoje, e não tive condições de me debruçar sobre o tema com o cuidado e atenção que estava a merecer". Em se tratando de HC, todavia, um prazo tão dilatado para pautar o julgamento, como ocorreu no

\footnotetext{
${ }^{10}$ São relacionados como votos disponíveis aqueles em que houve exposição de fundamentação em voto escrito ou transcrito (com declaração de voto) e manifestação em debates. A ausência de votos escritos proferidos por todos os ministros se impôs como dificuldade metodológica que se tentou superar pelo refinamento da primeira análise mais objetiva de catalogação de argumentos (seção 4.1). Partiu-se, então, à interpretação integral e refinada de cada voto, mediante valoração jurídica dos votos e seleção dos trechos efetivamente reveladores dos pontos centrais da argumentação de cada ministro (seção 4.2).
} 
primeiro caso, pode refletir igualmente o uso do poder de agenda para selecionar processos capazes de ensejar o resultado que se quer alcançar.

Embora nossa ênfase recaia sobre a inflexão promovida pelo HC2, é importante observar que o HC1 também marcou uma virada jurisprudencial da Corte. Até então, a tendência do tribunal era aceitar a execução provisória da pena após condenação em segunda instância. A revisão da tese, todavia, parece ter ocorrido de modo sinuoso até culminar com o HC1. A liminar foi concedida pelo ministro relator, Nelson Jobim, em 12/05/2004. Jobim foi substituído por Eros Grau e este, como relator, votou pela cassação da liminar em sessão da primeira Turma, em 26/10/2004. Ayres Britto pediu vistas e quando o julgamento foi retomado em 24/11/2004, a maioria da Turma decidiu por remetê-lo ao plenário da Corte. Quase quatro anos depois, já no plenário, Eros Grau mudou seu posicionamento e votou pela concessão do HC, liderando a maioria (não sem mais um pedido de vistas, por Menezes Direito, a protelar a decisão final) que consolidou o novo entendimento de afirmação da presunção de inocência.

Quanto ao HC2, um exame da ação penal mostra que não havia urgência que justificasse sua inclusão em pauta, já que o acusado se encontrava em liberdade, não havia risco de prescrição e o Ministério Público foi favorável à manutenção do posicionamento anterior sobre a presunção de inocência ${ }^{11}$. Surpreende ainda que o ministro relator Teori Zavascki, responsável por indicar o caso ao plenário do Supremo, e que havia concedido a liminar um ano antes, lideraria agora a decisão em sentido contrário, pela denegação da ordem e imediato cumprimento da pena após condenação em segundo grau. Como veremos adiante, razões de contexto podem ter levado Teori a utilizar seu poder de agenda como relator para levar o caso a plenário, reverter sua própria decisão anterior e fixar a nova tese.

Afinal, o que teria ocorrido entre o $\mathrm{HC} 1$ e o $\mathrm{HC} 2$, a ponto de levar o STF a alterar sua posição sobre tema tão sensível? Uma hipótese alternativa seria de que a Corte, seja pela chegada de novos ministros ao longo do período, seja por mudança incremental nos julgamentos de HC (na sua maioria feitos pelas Turmas), veio alterando paulatinamente seu entendimento sobre a matéria. Uma forma de avaliar essa hipótese é utilizar o índice de "punitivismo" desenvolvido por Duarte e Martins (2019). Os autores levantaram 8.334 julgamentos de HC pelo STF entre 2008 e 2017, e capturaram os votos individuais dos ministros nesses processos, a favor e contra a concessão de habeas corpus. A partir de 34.454 votos, desenvolveram um índice de "punitivismo" variando de 0 a 1 , no qual zero seria a posição mais punitivista e um a posição pró-liberdade do réu. Os resultados, inéditos, são apresentados por Duarte e Martins de forma desagregada por ministro e ano, o que

\footnotetext{
${ }^{11} \mathrm{O}$ acusado fora condenado a pena de 5 anos e 4 meses de reclusão, por fato cometido em 16/09/10. O prazo prescricional de 12 anos (artigo 109, inciso III, do Código Penal) foi interrompido e teve contagem reiniciada com a sentença condenatória, publicada em 19/11/13 (artigo 117, inciso IV, do Código Penal). Autos originais $\mathrm{n}^{\mathrm{o}}$ 0009715-92.2010.8.26.0268. Disponível em: $<$ http://esaj.tjsp.jus.br/cpopg/open.do>. Acesso em: 15 jun. 2016.
} 
facilita o trabalho dos pesquisadores interessados no tema. Tomando de empréstimo os dados, o gráfico 1 apresenta a evolução do grau médio de punitivismo (P) no STF entre 2008 e 2017. Apenas para facilitar a visualização, invertemos o índice de Duarte e Martins na forma 1-P, de modo que quanto maior o valor, maior o grau de punitivismo.

Gráfico 1 - Índice de punitivismo e dados dos habeas corpus



Fonte: Elaborado a partir de Duarte e Martins (2019)

De um modo geral, os ministros do Supremo votam mais pela negação do que pela concessão de HC. No período examinado, o índice médio de punitivismo (na nossa formulação invertida) ficou em 0,62. Carmem Lúcia e Edson Fachin se destacam entre os mais punitivistas (com 0,70 cada) e Marco Aurélio e Celso de Mello (com 0,53 e 0,54) são os mais liberais. Amaral (2016) já havia demonstrado a tendência de denegação de HC pelo STF em seu conjunto, o que pode ser atribuído ao fato de que os pedidos que ali chegam já foram negados por várias instâncias e, dada a apreciação sempre individualizada dos casos, o nível de observância de boas evidências deve ser alto, para que os ministros se inclinem a conceder a ordem.

Observe-se, contudo, que a hipótese alternativa de que o STF estava caminhando de modo incremental para uma posição mais punitivista pode ser refutada: o punitivismo vinha diminuindo, e não o contrário, desde 2012 até as vésperas do julgamento do $\mathrm{HC} 2$, que marcou a virada interpretativa do tribunal. Como a decisão se deu no início de 2016, é possível afirmar inclusive que ela foi a causa do aumento acentuado do índice naquele ano, e não a consequência de uma tendência que vinha supostamente se ampliando desde anos anteriores. 
Em resumo, o que explicaria, então, a célere, não provocada e surpreendente decisão do STF no HC2?

Parece razoável supor que fatores externos influenciaram a inclusão do habeas corpus em julgamento para viabilizar a mudança de posicionamento do STF. O exame dessa hipótese parte da análise qualitativa dos votos para se identificar a ratio decidendi dos julgados e, em seguida, contextualizar alguns fatores externos ao segundo julgamento e os efeitos esperados da mudança de posição da Corte sobre o funcionamento do sistema de justiça criminal.

\section{ANÁLISE DOS VOTOS PROFERIDOS NOS HABEAS CORPUS}

A identificação da ratio decidendi da Corte nem sempre é tarefa simples, diante do modelo deliberativo caracterizado pela fragmentação e individualização do processo decisório (ARGUELHES; RIBEIRO, 2018), que muitas vezes resulta em decisão final formada pela agregação ou soma dos votos individuais dos ministros (VOJVODC et al., 2009; SILVA, 2009).

O procedimento de identificação da ratio decidendi dos dois habeas corpus consistiu numa primeira análise mais objetiva, com a finalidade de realizar uma filtragem inicial dos tipos de argumentos empregados pelos ministros e facilitar uma segunda análise mais refinada dos votos.

\section{Filtragem objetiva dos argumentos}

A esquematização realizada a partir da leitura dos votos e da classificação dos argumentos resultou na identificação de 44 tipos de $\operatorname{argumentos}{ }^{12}$, que foram ponderados em função do número de aparições nos votos dos ministros. Em seguida, os tipos foram agregados em 6 classes gerais de argumentos, relacionados na tabela 3:

Tabela 3 - Incidência dos argumentos nos julgados

\begin{tabular}{lrrrr}
\hline \multicolumn{1}{c}{ Argumentos } & HC 84.078 (HC 1) & HC 126.292 (HC 2) \\
\hline A: Dispositivos e princípios constitucionais & 37 & $37,37 \%$ & 23 & $24,47 \%$ \\
\hline B: Legislação infraconstitucional & 12 & $12,12 \%$ & 13 & $13,83 \%$ \\
\hline C: Direito comparado e tratados & 8 & $8,08 \%$ & 8 & $8,51 \%$ \\
\hline D: Questões práticas externas ao Judiciário & 13 & $13,13 \%$ & 16 & $17,02 \%$ \\
\hline E: Comparação com outros julgados da Corte & 9 & $9,09 \%$ & 7 & $7,45 \%$ \\
\hline F: Questões práticas institucionais & 20 & $20,20 \%$ & 27 & $28,72 \%$ \\
\hline TOTAL & 99 & & 94 & \\
\hline
\end{tabular}

FONTE: Os autores.

${ }^{12}$ A tabela não consta no corpo do artigo, mas está à disposição do leitor interessado, que pode solicitá-la por e-mail aos autores. Os argumentos relevantes foram contabilizados nos diferentes votos ou debates orais, e ponderados conforme o número de aparições. Por outro lado, deve-se registrar que análise não discriminou trechos de extensões diversas sobre um mesmo "argumento relevante". 
É interessante observar como a estrutura argumentativa dos dois julgamentos não muda muito do primeiro ao segundo. Todavia, as diferenças observadas nas classes A, D e F apontam justamente para a tese defendida neste artigo. Os argumentos que envolveram dispositivos e princípios constitucionais compunham $37,37 \%$ do total de fundamentos identificados nos votos de todos os ministros que julgaram o HC1. Esse percentual cai para $24,47 \%$ no julgamento do HC2. A diminuição da concentração dessa classe de argumentos foi acompanhada de aumento daqueles relativos a questões práticas externas ao Poder Judiciário, que correspondiam a $13,13 \%$ dos argumentos no $\mathrm{HC} 1$ e passaram a $17,02 \%$ no $\mathrm{HC} 2$. O mesmo se diga das questões práticas institucionais, que ocupavam $20,20 \%$ dos argumentos no primeiro julgado e passaram à cifra de $28,72 \%$ no novo posicionamento da Corte.

Aprofundando a descrição dos argumentos A, D e F, o primeiro (A), identificado por "dispositivos e princípios", inclui os trechos de fundamentação dos votos nos quais houve referência a dispositivos ou princípios constitucionais, como ampla defesa, dignidade humana e proporcionalidade.

A classe $\mathrm{D}$, por sua vez, abrange argumentos pragmáticos que não se relacionam diretamente ao funcionamento institucional do STF, como influência dos meios de comunicação sobre o resultado de processos penais, a quantidade de presos provisórios do sistema penitenciário e a sensação de impunidade da sociedade.

Os argumentos classificados como "questões práticas institucionais" (classe F) guardam alguma relação com o funcionamento do STF, como estatísticas processuais da Corte, ocorrência da prescrição pelos sucessivos recursos interpostos perante o STF e agigantamento da Corte.

A tabela 3 indica que argumentos notadamente jurídicos (dispositivos e princípios constitucionais) cederam lugar a argumentos mais pragmáticos (questões práticas externas ao STF e questões práticas que se relacionam à instituição), o que sugere uma mudança de enquadramento do problema por parte da Corte. Tal mudança, entretanto, foi liderada por seus próprios ministros, sem provocação externa prévia que apontasse para essa direção, ou mesmo um processo cumulativo e de amadurecimento interno ao colegiado.

\section{Análise qualitativa dos votos}

A leitura dos votos proferidos no HC1 aponta que houve especial preocupação com a coerência da Corte ao tratar da exigência de trânsito em julgado de ações que envolviam direitos diversos de liberdade. Os ministros fizeram especial referência a dois julgados então recentes, o RE 482.006 e ADPF 144.

O RE 482.006 tinha por objeto a constitucionalidade de dispositivo de lei do Estado de Minas Gerais que autorizava a redução de vencimentos de servidores públicos processados criminalmente. Houve decisão unânime do plenário da Corte pelo reconhecimento da inconstitucionalidade do dispositivo, por violação aos 
artigos 5o, inciso LVII, e 37, inciso XV, da Constituição Federal, que abrigam, respectivamente, os princípios da presunção de inocência - tema central dos HCs aqui examinados - e a irredutibilidade de vencimentos.

No HC2, ministros invocaram o RE 482.006 para apontar a incoerência de se atribuir valor constitucionalmente maior ao patrimônio do que à liberdade, caso a Corte outorgasse ao princípio da presunção de inocência amplitude maior quando relacionado à redução de vencimentos de servidores públicos, deixando de fazer o mesmo quanto à restrição de liberdade decorrente da sentença condenatória não transitada em julgado ${ }^{13}$.

Cezar Peluso manifestou sua apreensão quanto à coerência que a Corte deve manter sobre temas próximos, caso se admita a privação de liberdade em circunstância similar àquela na qual não foi admitida a imposição de medida gravosa de caráter pecuniário. A preocupação foi expressa no voto escrito.

Celso de Mello não abordou o tema no voto escrito, mas ratificou em debates a preocupação de Peluso, tratando da coerência com julgados da Corte que estenderam o alcance da presunção de inocência a situações desvestidas de natureza criminal, fazendo menção expressa ao RE 482.006. Aberta divergência pelo voto do ministro Menezes Direito, Eros Grau manifesta confirmação de voto especificamente sobre esse tema, afirmando que "não é apenas ser coerente, mas a Corte há de dar à liberdade a mesma importância que dá à propriedade".

A ministra Cármen Lúcia ficou vencida, mas registrou que o tema foi "um dos maiores problemas que tive ao fazer meu voto"..$^{14}$ A Ministra Ellen Gracie, igualmente vencida, não expôs o tema em seu voto, a despeito de ter participado do julgamento do RE 482.006, que foi julgado por unanimidade no pleno. $\mathrm{O}$ ministro Menezes Direito $^{15}$, que recém ingressara na Corte por ocasião do julgamento do recurso extraordinário, também não fez menção ao tema no seu voto que abriu a divergência. $\mathrm{O}$ mesmo pode ser dito de Joaquim Barbosa, que não discorreu sobre ele, mas o contestou em debates, oferecendo argumento de que no processo penal o réu dispõe de outros meios de impugnação que não existem no processo cível.

A preocupação da Corte com a coerência entre julgados também foi manifestada nos votos que indicaram, na fundamentação, a ADPF 144. Neste julgamento, vencidos os ministros Carlos Britto e Joaquim Barbosa, a maioria decidiu que a

\footnotetext{
${ }^{13} \mathrm{O}$ Ministro Eros Grau utiliza o argumento ao afirmar que "a Corte que vigorosamente prestigia o disposto no preceito constitucional em nome da garantia da propriedade certamente não o negará quando se trate de garantia da liberdade. Não poderá ser senão assim, salvo a hipótese de entender-se que a Constituição está plenamente a serviço da defesa da propriedade, mas nem tanto da liberdade".

${ }^{14} \mathrm{O}$ voto não está disponível no sítio eletrônico do STF.

${ }^{15} \mathrm{O}$ ministro Menezes Direito foi nomeado para o Supremo Tribunal Federal em 05/09/07 e o RE 482.006 foi julgado em 07/11/07. Disponível em: <http://www.stf.jus.br/portal/ministro/ verMinistro.asp?periodo=stf\&id=43>. Acesso em: 08 jun. 2016.
} 
Justiça Eleitoral não pode negar registro de candidatos que respondem a processos judiciais, sem condenações com trânsito em julgado, para que possam concorrer a cargos eletivos (BRASIL, 2009a). Dos sete ministros que formaram maioria no HC1, quatro mencionaram expressamente a discussão sobre presunção de inocência e necessidade de trânsito em julgado na seara eleitoral (Ayres Brito, Cezar Peluso, Celso de Mello e Gilmar Mendes) ${ }^{16}$.

A leitura dos votos também indica que no $\mathrm{HC} 1$ houve referências explícitas a dispositivos legais, notadamente a lei de execuções penais, com argumentos que também se amparam na busca de coerência entre a solução encontrada pela Corte e o regramento fixado pelo legislador ${ }^{17}$. Os ministros Eros Grau, Cesar Peluso e Celso de Mello discorreram com alguma ênfase sobre o tema, no sentido exposto pelo Ministro Eros Grau, de que "se é vedada a execução da pena restritiva de direito antes do trânsito em julgado da sentença, com maior razão há de ser coibida a execução da pena privativa de liberdade - indubitavelmente mais grave enquanto não sobrevier título condenatório definitivo".

A efetividade da justiça penal, o uso abusivo de recursos, a crítica ao sistema recursal e a sensação de impunidade foram temas debatidos pelos ministros, mas o entendimento fixado pela maioria considerou que tais argumentos não são relevantes no plano normativo. Na parte final de seu voto, o ministro Eros Grau faz referência inclusive "a uma possível reforma processual", o que expressa postura mais deferente ao legislador, endereçando à arena legislativa a solução de problemas relativos a segurança pública e direito processual penal. Foi o que fez, inclusive, o ministro Peluso ao oferecer ao Congresso, em 2011, uma Proposta de Emenda Constitucional (PEC 15/2011, também chamada de PEC dos Recursos) destinada a impor a execução das decisões judiciais tomadas pelos tribunais de segunda instância (BRASIL, 2011b).

A mesma preocupação com a separação entre poderes Legislativo e Judiciário foi externada no voto do ministro Gilmar Mendes, quando tratou dos abusos no uso da prisão preventiva e da efetividade da justiça criminal, referindo-se expressamente à atuação do legislador ${ }^{18}$.

Os votos que utilizaram estatísticas se concentraram em dados sobre número de recursos bem-sucedidos em ações penais. Esse tema poderia guardar conexão com

\footnotetext{
${ }^{16}$ Não está disponível voto escrito do ministro Ricardo Lewandowski, que votou com a maioria.

${ }^{17}$ A citação a dispositivos da Lei de Execuções penais foi feita pelos ministros Eros Grau, Cezar Peluso e Celso de Mello. O ministro Joaquim Barbosa fez referência expressa ao tema e atribuiu interpretação diversa para acomodar a conclusão de seu voto entre os vencidos.

18 “... há meios e modos de lidar com esse tema, a partir da própria visão ampla da prisão preventiva, para que, naqueles casos mais graves, o próprio legislador, aqui, possa atuar. Penso que há proposta nesse sentido, no sentido de redimensionar a ideia da prisão preventiva, inclusive para torná-la mais precisa, porque, obviamente, vê-se que há um abuso da prisão preventiva" (BRASIL, 2009b, p. 1184).
} 
questões pragmáticas indicativas de preocupações institucionais ou de atuação no campo de políticas públicas.

As estatísticas sobre movimentação processual divulgadas pelo Supremo Tribunal Federal e o teor dos votos apontam, no entanto, que os elementos pragmáticos vinculados aos dados estatísticos citados se referem mais à finalidade de tutela das garantias dos acusados do que preocupações institucionais ou exercício de atividade jurisdicional sobre competências ordinariamente atribuídas ao Legislativo ou Executivo.

Os ministros Cezar Peluso, Celso de Mello e Gilmar Mendes, indicando dados que foram relatados por Lewandowski, fizeram menção expressa ao que entendem ser um elevado número de recursos acolhidos na esfera penal, fato que corroborou o entendimento de inconstitucionalidade da prisão antes do trânsito em julgado pelo risco concreto de prisões indevidas.

Tabela 4 - Estatística do STF de processos distribuídos (D) e com julgamentos (J) *

\begin{tabular}{ccccccc} 
& \multicolumn{2}{c}{2004} & \multicolumn{2}{c}{2008} & \multicolumn{2}{c}{ 2004-2008 } \\
\hline & D & J & D & J & D & J \\
\hline RE & 26.534 & 32.694 & 21.526 & 37.644 & $-18,87 \%$ & $15,14 \%$ \\
\hline HC & 1.284 & 1.437 & 3.560 & 4.282 & $177,26 \%$ & $197,98 \%$ \\
\hline AP & 21 & 21 & 26 & 33 & $23,81 \%$ & $57,14 \%$ \\
\hline Inq & 102 & 143 & 110 & 133 & $7,84 \%$ & $-6,99 \%$ \\
\hline
\end{tabular}

FONTE: Os autores, a partir do sítio eletrônico do STF.

*(RE - recurso extraordinário, HC - habeas corpus, AP - ação penal, Inq - inquérito)

O número de habeas corpus distribuídos e julgados no período talvez guarde relação com as conclusões dos ministros que formaram maioria. Entre 2004 e 2008 houve acréscimo de 177,26\% do número de HC distribuídos e 197,98\% de HC julgados (tabela 4).

O elevado número desta ação constitucional que tutela o direito de liberdade pode ter fornecido ao tribunal evidências sobre possíveis abusos e ilegalidades verificados nas instâncias ordinárias do Judiciário. Essa suposição se confirma pela manifestação no voto do ministro Gilmar Mendes: "É um mundo de horrores a Justiça criminal brasileira, muitas vezes com a conivência da Justiça e do Ministério Público". É bom lembrar que à época, Mendes andava às turras com as operações de combate à corrupção lideradas pela Polícia Federal e Ministério Público, com anuência de juízes, a quem acusava de conluio e abuso de autoridade (O GLOBO, 2008).

$\mathrm{Na}$ verdade, a tese garantista adotada no julgamento do $\mathrm{HC} 1$ respondeu a um contexto mais amplo, marcado pela crescente preocupação do tribunal com a 
situação do sistema prisional brasileiro. Numa sequência de decisões, da qual o $\mathrm{HC} 1$ foi uma das primeiras, o tribunal forjou o que o ministro Roberto Barroso denominaria de um conjunto de medidas a compor "a agenda mínima de discussão em torno de uma nova política prisional" e que Rosa Weber sintetizou como a "agenda do sistema penitenciário que vem sendo paulatinamente conduzida por este Supremo Tribunal Federal" (BRASIL, 2017, p. 70-128). No RE 592581, o tribunal afastou o argumento da reserva do possível nos casos de obras consideradas emergenciais em estabelecimentos prisionais, necessárias para assegurar a dignidade humana dos presos. A partir do RE 641320 se estabeleceu a tese em Repercussão Geral (423) que trata de medidas alternativas a serem adotadas por juízes de execução penal, na falta de vagas no sistema penitenciário. O RE 841526 fixou outra tese em Repercussão Geral (592), estabelecendo que o Estado é responsável pela morte de detentos. Finalmente, o RE 580252 fixou a obrigação de indenização por danos morais sofridos por presos submetidos a condições desumanas, enquanto a ADPF 347/2015 resultou na declaração do "estado de coisas inconstitucional do sistema penitenciário brasileiro, presente o quadro de violação massiva e persistente de direitos humanos dos detentos, decorrente de falhas estruturais e da falência de políticas públicas" (BRASIL, 2017, p. 129).

Todavia, é interessante observar como essa "agenda" voltada à intervenção na policy carcerária, marcada pelo garantismo e tangenciando o abolicionismo penal, cederá lugar a uma outra, de endurecimento do punitivismo conforme tem início (em 2014), e se expande de maneira inédita nos anos seguintes, o combate à corrupção política na forma da Operação Lava Jato.

Passando-se então à análise do $\mathrm{HC} 2$, vários aspectos extraídos dos votos, das estatísticas da Corte e do contexto social auxiliam a compreender a mudança de posicionamento em tão curto espaço de tempo.

$\mathrm{O}$ voto do ministro relator Teori Zavascki parte de fundamento estritamente jurídico sobre duas peculiaridades dos recursos especiais e extraordinários, ausência de efeito suspensivo e não abrangência de matéria fática, temas que também integravam os fundamentos dos votos vencidos no HC1. Estes temas, sozinhos ou cumulados, também constaram nos votos de Cámen Lúcia, Gilmar Mendes, Fachin, Barroso e Fux.

A outra referência a textos legais no voto do relator ocorre com a citação da Lei Complementar 135/2010 (ficha limpa), que prevê como hipótese de inelegibilidade a existência de sentença condenatória sem exigir o trânsito em julgado, tema que constou na fundamentação de Gilmar Mendes e Luiz Fux ${ }^{19}$. Também há citação de dispositivo que trata do início do prazo prescricional quando se alega que "os apelos extremos [recurso especial e recurso extraordinário]...ao invés de constituir um instrumento de garantia da presunção de não culpabilidade do apenado, acabam representando um mecanismo inibidor da efetividade da jurisdição penal".

${ }^{19} \mathrm{O}$ dispositivo teve sua constitucionalidade reconhecida no julgamento das ADC no 29 e 30/2011. 
Os demais argumentos do relator revelam que o mote principal é a busca de efetividade da função jurisdicional, notadamente quando afirma que "a jurisprudência que assegura, em grau absoluto, o princípio da presunção da inocência...tem permitido e incentivado, em boa medida, a indevida e sucessiva interposição de recursos da mais variada espécie, com indisfarçados propósitos protelatórios, visando, não raro, à configuração da prescrição da pretensão punitiva ou executória".

A mesma preocupação aparece expressamente nos votos de Gilmar Mendes, Luís Barroso e Cármen Lúcia (debates) ${ }^{20}$, e indiretamente no voto de Edson Fachin, quando faz menção ao "agigantamento dos afazeres deste Supremo Tribunal Federal" e quando afirma que "os mecanismos legais destinados a repelir recursos meramente protelatórios são ainda muito incipientes".

$\mathrm{O}$ voto do ministro Gilmar Mendes, que participou do julgamento do $\mathrm{HC} 1$ e modificou seu posicionamento, reforça a conclusão de que o argumento principal para mudança da jurisprudência da Corte reside na busca de efetividade da jurisdição penal, notadamente quando, logo no início de sua manifestação, afirmou que "de uns tempos para cá, eu tenho me proposto a refletir novamente sobre aquela nossa decisão. E casos graves têm ocorrido que comprometem mesmo a efetividade da justiça", para pouco depois afirmar que "essa massa de recursos faz que tenhamos esse quadro constrangedor de impunidade".

$\mathrm{O}$ ministro Barroso discorreu longamente sobre questões relacionadas à efetividade da jurisdição penal. Ao elencar os fundamentos pragmáticos que justificariam a mudança da posição do STF, fez menção expressa à "inegável dimensão política" da atuação judicial quando a questão envolve jurisdição constitucional e "os chamados casos difíceis", pelo elemento criativo da atividade de interpretação e em razão das "consequências práticas de suas decisões". Interessante destacar que as palavras impunidade, efetividade e credibilidade aparecem, respectivamente, 12, 7 e 9 vezes no voto de 27 páginas do ministro Barroso.

A finalidade mais pragmática e voltada à busca de efetividade da jurisdição penal na modificação do posicionamento da Corte também parece se expressar na ausência de discussão sobre um dos pontos fundamentais no julgado anterior, a coerência da Corte ao tratar temas correlatos.

Os ministros que formaram maioria não enfrentaram especificamente os argumentos da tese vencedora no HC1 e apenas a ministra Rosa Weber, em voto de poucas linhas, levantou a preocupação com "o princípio da segurança jurídica, sobretudo quando esta Suprema Corte enfrenta questões constitucionais", tendo afirmado que "há questões pragmáticas envolvidas, não tenho a menor dúvida,

\footnotetext{
${ }^{20}$ Cármen Lúcia: "A Justiça que tarda falha, é claro, mas, em alguns casos, a Justiça que tarda na sua execução deixa de poder ser prestada" (BRASIL, 2016, p. 66).
} 
mas penso que o melhor caminho para solucioná-las não passa pela alteração, por esta Corte, de sua compreensão sobre o texto constitucional no aspecto".

Diversamente do que se observa no HC1, vê-se que não há preocupação em deixar ao legislador a solução dos problemas no sistema recursal, o que igualmente aponta para uma postura institucional mais ativista da Corte. Ademais, a PEC dos Recursos, patrocinada por Peluso em 2011, além de desfigurada pelo Senado, terminou sem votação e foi arquivada ao término de duas legislaturas consecutivas, em 2014 e 2018 (BRASIL, 2011a).

Por outro lado, a alegada necessidade de aumento da efetividade da jurisdição penal parece não encontrar fundamento nos dados processuais divulgados pelo STF.

A efetividade referida guarda relação direta com o RE (recurso extraordinário), modalidade recursal que impediria a execução da condenação em segunda instância, caso mantida a posição fixada no HC1. Prevalecendo este entendimento (HC1), espera-se maior uso do RE com a finalidade de obstar o trânsito em julgado da condenação em segunda instância e postergar o cumprimento da pena. O habeas corpus não permitiria tal resultado, pois se trata de ação constitucional que não impede o trânsito em julgado da condenação em segunda instância. Por outro lado, prevalecendo a nova posição (HC2), espera-se o aumento do uso do habeas corpus como forma de obter a suspensão liminar da execução da pena.

Entre 2008 e 2015, houve diminuição de 47,06\% dos recursos extraordinários distribuídos (tabela 5), em boa medida como resultado da reforma constitucional do Judiciário de 2004, especialmente a introdução do mecanismo da Repercussão Geral. A acentuada redução do número de REs, portanto, deveria desautorizar a afirmação de que a posição fixada no HC1 redundou em aumento do número de REs.

Paralela a esta redução, houve aumento de $150 \%$ das ações penais distribuídas no tribunal, envolvendo autoridades com prerrogativa de foro, tendência que tem início com o Mensalão e se amplia com as grandes operações de combate à corrupção, com destaque para a Lava Jato. Este crescimento pode ter levado os ministros a considerarem a necessidade de reorganizar o fluxo do sistema de justiça criminal, assegurando maior definitividade às decisões de instâncias inferiores e reservando mais tempo e recursos para funcionar como foro especial. Essa estratégia de remodelagem institucional seria completada com a decisão de restringir a extensão do próprio foro privilegiado, no julgamento da ação penal 937 (3-5-2018). 
Tabela 5 - Estatística do STF de processos distribuídos (D) e com julgamentos (J) *

2008 2015

2008-2015

\begin{tabular}{lrrrrrc}
\hline & D & J & D & J & D & J \\
\hline RE & 21.526 & 37.644 & 11.396 & 11.830 & $-47,06 \%$ & $-68,57 \%$ \\
\hline HC & 3.560 & 4.282 & 4.441 & 5.933 & $24,75 \%$ & $38,56 \%$ \\
\hline AP & 26 & 33 & 65 & 128 & $150,00 \%$ & $287,88 \%$ \\
\hline Inq & 110 & 133 & 234 & 370 & $112,73 \%$ & $178,20 \%$ \\
\hline
\end{tabular}

Fonte: Os autores, a partir do sítio eletrônico do STF.

* (RE - recurso extraordinário, HC - habeas corpus, AP - ação penal, Inq - inquérito)

Um aspecto relevante que poderia passar despercebido pela leitura dos votos no HC2 consiste na ausência de debates sobre a constitucionalidade do artigo 283 do Código de Processo Penal, que relaciona como hipóteses de prisão, além das modalidades provisórias (flagrante, temporária e preventiva), apenas a prisão decorrente de "sentença condenatória transitada em julgado".

O dispositivo foi tratado pelo ministro Barroso em apenas um dos cinquenta parágrafos do voto escrito, sem declaração expressa de sua inconstitucionalidade, e não foi citado no voto oral proferido por ele no dia da sessão. A omissão da Corte em tratar do dispositivo legal, desprezando a vontade expressa do legislador, redundou no ajuizamento das Ações Declaratórias de Constitucionalidade (ADC) no 43 e 44, distribuídas em maio de 2016, mas o indeferimento das medidas cautelares nestas ADCs implicou na manutenção da tese que restou decidida no $\mathrm{HC} 2 .^{21}$

A leitura dos votos também permitiu concluir que os ministros não vislumbraram incoerência com as decisões recentes do STF sobre a crise do sistema penitenciário, conforme vimos anteriormente.

A questão da falência do sistema prisional foi levantada pelo ministro Lewandowski, que destacou o possível efeito de aumento da população carcerária em razão da mudança no posicionamento da Corte. Contrapondo-se a ele, Luiz Fux argumentou que grande parte da população carcerária se refere a presos provisórios e preventivos, e que a modificação da jurisprudência teria como consequência "a liberação de quem está injustamente preso, provisoriamente ou preventivamente, e o recolhimento daqueles que foram condenados em segundo grau".

${ }^{21} \mathrm{Na}$ apreciação preliminar da matéria, o tribunal argumentou que o novo art. 283 do CPP só poderia ser interpretado conforme a constituição, no sentido de não impedir a execução da pena após condenação em segunda instância, pois a carta não impediria essa interpretação, sic erat scriptum. No julgamento de mérito, realizado quando este artigo já estava concluído, em novembro de 2019, a maioria dos ministros não adotou a regra da interpretação conforme (ver nota 26). 
Lewandowski, que fora o único a levantar a questão da falência do sistema penitenciário e tinha sido relator do RE 592.581, não apresentou argumentos que indicassem sua conclusão sobre incoerência entre os julgados. Ao contrário, limitou-se a ironizar a tese da redução dos presos provisórios, quando afirmou que "nós vamos trocar duzentos e quarenta mil presos provisórios por duzentos e quarenta mil presos condenados em segundo grau".

Seja como for, nenhum dos ministros apresentou dados que comprovassem a relação de causalidade alegada.

$O$ voto do ministro Barroso também não reconheceu incoerências entre a revisão do posicionamento da Corte e o reconhecimento, pelo qual tanto havia se empenhado anteriormente, de falência do sistema penitenciário e de superpopulação carcerária. Ao tratar da seletividade do sistema criminal, afirmou que "a alteração da compreensão do STF acerca do momento de início de cumprimento da pena deverá ter impacto positivo sobre o número de pessoas presas temporariamente - a maior eficiência do sistema diminuirá a tentação de juízes e tribunais de prenderem durante a instrução". O Ministro igualmente não apresentou dados que demonstrassem a causalidade alegada.

O debate dos ministros sobre a falência do sistema penitenciário é indicativo dos efeitos esperados com a mudança de posição da Corte acerca da presunção de inocência. Os ministros expõem entendimento de que a autorização da prisão com a condenação em segunda instância não acarretaria aumento da população carcerária. A explicitação de tal argumento sugere que a repercussão esperada com a mudança de posição da Corte não se refere aos presos de baixa renda, que constituem a quase totalidade da população carcerária brasileira. Ou seja, os ministros esperavam efeitos específicos sobre acusados específicos, provavelmente aqueles alcançados pelas operações de combate ao crime organizado e à corrupção.

Em suma, as análises permitem concluir que, no $\mathrm{HC} 1$, a atuação da Corte focouse na efetividade das garantias constitucionais dos acusados, na coerência da interpretação constitucional de princípios e na preocupação quanto à separação de poderes, tendo como pano de fundo a crise do sistema penitenciário. A análise qualitativa do $\mathrm{HC}$, por outro lado, evidencia que a mudança de posicionamento foi fundamentada, de forma preponderante, na preocupação com a efetividade da justiça penal diante da ineficiência do sistema legal de recursos.

Considerando que os argumentos dos ministros apontam que a eficiência buscada não se refere à justiça penal que incide sobre a população de baixa renda, parece relevante identificar outros fatores externos ao julgado que possam explicar a mudança da posição.

\section{CEnÁRio da MUdANÇa: OPERAÇão LaVa Jato}

A questão da corrupção é tema candente na história política brasileira. Seja como um problema em si, seja como arma da disputa política, combatê-la sempre 
foi uma bandeira levantada por inúmeros atores políticos e institucionais. Com a redemocratização do país e a reorganização constitucional de 1988, houve um gradual e consistente processo de fortalecimento das instituições de controle e o próprio sistema de justiça se viu progressivamente desafiado a liderar o combate à corrupção. No pós-1988, inovações institucionais como o inquérito civil e a ação civil por improbidade administrativa foram utilizados por promotores e procuradores do Ministério Público para levar políticos e administradores às barras da justiça e à prestação de contas. Desde o início dos anos 2000, com a reestruturação da Polícia Federal, o combate à corrupção retomou a via criminal e se expandiu significativamente na forma das grandes operações policiais, especialmente no plano federal (ARANTES, 2011a; 2011b).

Graças a uma série de transformações legais, institucionais, mas também materiais e tecnológicas, associadas a uma maior articulação entre juízes, procuradores e delegados, as investigações se tornaram mais eficientes e as denúncias passaram a alcançar, de fato e de modo contundente, lideranças políticas, governantes e empresários do crime organizado. No contexto de afirmação desse novo modus operandi das instituições de justiça criminal, pode-se considerar que o julgamento do "Mensalão" (Ação Penal 470, no STF) foi um grande divisor de águas, representando marco importante contra a chamada impunidade da classe política brasileira.

A preocupação do Supremo com a efetividade da justiça penal, expressa nos votos de alguns de seus ministros, parece encontrar uma de suas causas nesse contexto de ascensão das instituições de justiça no combate à corrupção e ao crime organizado. Ilustrativos dessa tendência são alguns trechos do voto do ministro Barroso, que fundamentou expressamente a necessidade de mudança da jurisprudência na ideia de diminuir "o grau de seletividade do sistema punitivo brasileiro, tornando-o mais republicano e igualitário" e reduzindo "os incentivos à criminalidade de colarinho branco".

A influência da opinião pública - forte componente no contexto da proliferação das operações de combate à corrupção e da transmissão ao vivo dos julgamentos pela TV Justiça - pode ser observada em manifestação do ministro Fux, quando afirma que a interpretação que se atribuía ao princípio da presunção de inocência "efetivamente não corresponde à expectativa da sociedade", a qual "não aceita essa presunção de inocência de uma pessoa condenada que não para de recorrer, com a seguinte disfunção, a prescrição".

O cada vez mais inflamado debate sobre a impunidade dos crimes de colarinho branco e da classe política atingiu seu ápice justamente no julgamento da Ação Penal 470. Entretanto, mal haviam terminadas as sessões destinadas aos últimos embargos no processo do Mensalão e uma nova operação é deflagrada em 17/03/2014, aquela que alcançaria dimensões absolutamente inéditas: a Lava Jato.

Diferentemente do "Mensalão", a Lava Jato foi uma operação que começou de baixo para cima, a partir da primeira instância da Justiça Federal de Curitiba (PR). 
Na medida em que foi se desdobrando em inúmeras fases, atingindo os diversos elos do esquema de desvios da Petrobrás, foi ficando mais claro que seu alvo central era constituído de importantes atores políticos, de diferentes partidos, mas especialmente concentrados no Partido dos Trabalhadores e em sua principal liderança, o ex-presidente Lula. Se o "Mensalão" representou um ponto de inflexão na teoria de que o foro especial por prerrogativa de função sempre beneficia as altas autoridades, a Lava Jato representou outro ponto de inflexão na teoria de que a justiça criminal de primeiro grau seria incapaz de desvelar grandes esquemas de corrupção e punir seus responsáveis. A operação inovou no uso inédito e em grande número das colaborações premiadas e prisões preventivas envolvendo as classes política e empresarial, que até então permaneciam distantes dos balcões da justiça penal e especialmente do sistema penitenciário. Além disso, o trâmite das medidas de persecução criminal foi diuturnamente acompanhado pela mídia, que contribuiu para a formação de opinião pública interessada no curso e no apoio das ações da Força-Tarefa de Curitiba.

A importância da colaboração premiada para os resultados da operação está estampada no sítio eletrônico da força tarefa do $\mathrm{MPF}^{22}$. O uso deste instituto jurídico foi defendido pelo juiz federal Sérgio Moro como meio de assegurar efetividade na punição de crimes de colarinho branco, em artigo jurídico publicado em 2004 (MORO, 2004). O magistrado, além de ser o responsável pelas ações penais da Lava Jato, havia ocupado a posição de juiz instrutor no gabinete da ministra Rosa Weber, na época do julgamento do Mensalão (FOLHA DE SÃO PAULO, 2012).

Segundo informações divulgadas pela mídia, em dezembro de 2014 (O GLOBO, 2014) havia 12 acordos de colaboração premiada celebrados, número que passou a 40 em janeiro de 2016 (UOL, 2016). Os dados divulgados pela força-tarefa MPF indicam que até janeiro de 2020 foram homologados 49 acordos de colaboração premiada pela Justiça Federal em Curitiba e 183 pelo Supremo Tribunal Federal23.

Diversos fatores podem contribuir para a elevação do número de colaborações premiadas, grande parte deles relacionados à decisão pessoal do investigado/acusado de aderir ao instituto para obter redução ou isenção de pena.

Espera-se que quanto maior o temor da condenação, maior será o incentivo a colaborar. A expectativa quanto ao risco de condenação se refere à qualidade do acervo de provas e à lisura procedimental, ou seja, à existência de boas provas do crime e poucas chances de reconhecimento de nulidades processuais. Neste caso, a

\footnotetext{
22 “Se não fossem os acordos de colaboração pactuados entre procuradores da República e os investigados, o caso Lava Jato não teria alcançado evidências de corrupção para além daquela envolvendo Paulo Roberto Costa." Disponível em: $<$ http://lavajato.mpf.mp.br/atuacao-na-1ainstancia/investigacao/colaboracao-premiada>. Acesso em: 13 jun.2017.

${ }^{23}$ Disponível em: <http://www.mpf.mp.br/grandes-casos/lava-jato/resultados $>$. Acesso em 01 mar. 2020.
} 
escolha do momento de colaborar dependerá da expectativa quanto à duração do processo. Quanto maior a expectativa de rápido encerramento, maior será o incentivo a buscar a colaboração premiada, em especial porque a lei prevê a redução dos benefícios quando a colaboração é posterior à sentença (artigo $4^{\circ}$, parágrafo $5^{\circ}$, da Lei 11.280/2013).

Diante das especificidades que marcaram o julgamento do HC2, expostas anteriormente, e somadas ao contexto de uma nova e abrangente operação de combate à corrupção, parece razoável sustentar a hipótese de que a mudança de posicionamento do STF tenha se dado em função da necessidade de incluir "por cima" o último elo da corrente lançada a partir de Curitiba, levando os investigados a adotarem o comportamento esperado pelos idealizadores da Lava Jato.

Dentre os efeitos esperados, a conhecida estratégia de postergar o cumprimento da pena por meio de sucessivos recursos junto ao STJ e STF após condenação em segunda instância restaria fortemente comprometida. Uma vez fixado o entendimento de que o cumprimento da pena se inicia com a condenação em segunda instância, o uso de novos recursos não mais permitiria a permanência em liberdade até decisão final dos tribunais superiores (STJ e STF). Mais do que isso, a mudança afetaria o comportamento dos investigados e acusados num ponto central e estratégico da Lava Jato: a celebração de acordo de colaboração premiada.

Se pelo alto as portas da justiça se fechavam com o novo entendimento adotado pelo STF, por baixo a velocidade imposta pela Justiça da $4^{\mathrm{a}}$ Região provavelmente afetou o cálculo de investigados/acusados quanto à urgência de aderirem a acordos de delação. A primeira observação a ser feita reside na edição de sucessivos atos normativos pelo Tribunal Regional Federal da $4^{a}$ Região, com efeitos a partir de 19/12/14, prevendo a suspensão temporária da distribuição de processos na $13^{a}$ Vara Criminal de Curitiba, sede da operação Lava Jato (Resoluções TRF4 n. 164, de 19/12/2014; n. 8, de 11/02/15; n. 120, de 19/11/15; n. 7, de 12/02/16; n. 38, de 6/05/16; n. 78 , de $9 / 08 / 16$ ).

As sucessivas resoluções não incluíram, na medida de suspensão da distribuição, os casos em conexão, ou seja, procedimentos e ações penais decorrentes da mesma operação. Além disso, a partir de 12/05/16, a suspensão se restringiu a novas distribuições ao juiz titular (responsável pela operação). A medida provavelmente contribuiu para a redução do volume anual de feitos distribuídos: 37,72\% entre 2014 e 2015, e 21,63\% entre 2015 e 201624, e na medida em que a distribuição foi reduzida, as ações instauradas em razão da operação puderam tramitar mais rapidamente.

Os dados públicos sobre movimentação processual das ações penais em curso são reveladores do tempo estimado para que os acusados sejam julgados em

\footnotetext{
${ }^{24}$ Estatísticas Processuais de $1^{\circ}$ e $2^{\circ}$ graus e JEF. Consulta mês a mês de janeiro de 2014 a dezembro de 2016. Processos distribuídos e julgados anualmente. Disponível em: $<\mathrm{http}: / /$ www2.trf4.jus.br/trf4/controlador.php?acao=estatistica_nova_provimento2>. Acesso em: 10 maio 2017.
} 
segunda instância. O tempo de duração das ações então sentenciadas - entre distribuição da denúncia e sentença - vai de 109 a 1562 dias. Trinta e duas das quarenta e três ações encerraram-se na primeira instância em menos de um ano. ${ }^{25}$.

No que diz respeito às apelações julgadas pelo TRF4, o tempo decorrido entre a remessa do recurso e seu julgamento variou de 85 a 753 dias, sendo que quatorze julgamentos ocorreram em menos de um ano. Além disso, conforme dados divulgados pelo TRF4, até abril de 2017 a operação já havia produzido 645 processos em segunda instância, 419 relativos a pedidos de habeas corpus, dos quais 365 já foram analisados, a indicar o esforço dos desembargadores em imprimir ritmo acelerado na apreciação de processos relativos à operação (BRASIL, 2017).

A celeridade processual imposta pela Justiça Federal da $4^{\underline{a}}$ Região tornou-se evidente aos olhos de investigados/acusados e de seus advogados, afetando assim seus cálculos sobre a conveniência da colaboração premiada. Por sinal, quando o tribunal mudou seu posicionamento sobre o princípio da presunção da inocência, havia dezessete ações penais da Lava Jato sentenciadas, dezesseis delas em menos de um ano.

Os gestores e executivos de cinco grandes empreiteiras - OAS, Galvão Engenharia, ENGEVIX, Mendes Júnior e Camargo Correa - foram condenados em primeira instância entre julho e dezembro de 2015, poucos meses antes do julgamento do HC2 (17 de fevereiro de 2016). As cinco ações penais a que se referem estas condenações abrangem 15 executivos condenados e 6 absolvidos. Excluída uma condenação à pena de 4 anos de reclusão em regime aberto, aos demais foram impostas penas de encarceramento em regime fechado, que variaram de 9 anos e 6 meses a 19 anos e 4 meses de reclusão, resultado que foi amplamente divulgado pela imprensa. Apenas dois executivos já tinham celebrado acordo de colaboração premiada e obtiveram redução da pena nos termos do acordo (tabela $6)$.

\footnotetext{
${ }^{25}$ A relação das ações, com respectivas datas de distribuição, sentença e julgamento da apelação, consta em tabela que está à disposição do leitor interessado no acesso. As informações podem ser verificadas individualmente no sítio eletrônico do Tribunal Regional Federal. Disponível em: $<$ https://eproc.jfpr.jus.br/eprocV2/>. Acesso em: 10 maio 2017.
} 
Tabela 6- Empreiteiros julgados em primeira instância antes do HC2

\begin{tabular}{|c|c|c|c|c|c|}
\hline Ação Penal & Empreiteira & Pena ser & redução & Regime & Acordo \\
\hline 5083401-18.2014 & Mendes Júnior & 19 anos e & 4 meses & Fechado & Não \\
\hline 5083351-89.2014 & Engevix & 19 anos & & Fechado & Não \\
\hline 5083401-18.2014 & Mendes Júnior & 17 anos e & 4 meses & Fechado & Não \\
\hline 5083376-05.2014 & OAS & 16 anos e & 4 meses & Fechado & Não \\
\hline 5083376-05.2014 & OAS & 16 anos e & 4 meses & Fechado & Não \\
\hline 5083258-29.2014 & Camargo Correa & 15 anos e & 10 meses & Fechado & Sim \\
\hline 5083258-29.2014 & Camargo Correa & 15 anos e & 10 meses & Fechado & Sim \\
\hline 5083360-51.2014 & Galvão Engenharia & 13 anos e & 2 meses & Fechado & Não \\
\hline 5083360-51.2014 & Galvão Engenharia & 12 anos e & 5 meses & Fechado & Não \\
\hline 5083360-51.2014 & Galvão Engenharia & 11 anos e & 8 meses & Fechado & Não \\
\hline 5083376-05.2014 & OAS & 11 anos & & Fechado & Não \\
\hline 5083376-05.2014 & OAS & 11 anos & & Fechado & Não \\
\hline 5083401-18.2014 & Mendes Júnior & 10 anos & & Fechado & Não \\
\hline 5083258-29.2014 & Camargo Correa & 09 anos e & 6 meses & Fechado & Não \\
\hline 5083376-05.2014 & OAS & 04 anos & & Aberto & Não \\
\hline 5083360-51.2014 & Galvão Engenharia & Absolvido & & & \\
\hline $5083351-89.2014$ & Engevix & Absolvido & & & \\
\hline $5083351-89.2014$ & Engevix & Absolvido & & & \\
\hline $5083351-89.2014$ & Engevix & Absolvido & & & \\
\hline 5083401-18.2014 & Mendes Júnior & Absolvido & & & \\
\hline 5083401-18.2014 & Mendes Júnior & Absolvido & & & \\
\hline
\end{tabular}

A pesquisa processual aponta que as cinco ações penais foram contestadas perante o STF em pelo menos 6 habeas corpus, 6 reclamações e 5 agravos regimentais em RE, todos sob relatoria do Ministro Teori Zavascki, que também foi relator do HC2.

No contexto maior da operação Lava Jato, especialmente com as denúncias envolvendo altas autoridades a partir de 2015, vale lembrar que o STF foi colocado no centro da crise política, teve que arbitrar o processo de impeachment de Dilma Roussef e lidar com os desdobramentos quase diários da Lava Jato, seja na forma de recursos vindos de baixo, seja pelos inquéritos e processos em tramitação no tribunal com foro especial por prerrogativa de função. Antes de pautar o HC2, Zavascki já tinha uma ampla noção do espectro alcançado pela operação, e inclusive já havia homologado colaborações premiadas celebradas pela Procuradoria Geral da República (PET 5851, 5209 e 5244).

Apesar de ainda não ser possível a catalogação e análise detalhada de todos os acordos de delação celebrados no âmbito da operação, pois muitos dados ainda estão sob sigilo, houve incremento significativo do número de colaborações 
premiadas celebradas entre a véspera do julgamento do HC2 (40 acordos) e junho de 2017 (158 acordos).

Esse elevado número sugere que a decisão do STF foi um dos fatores que contribuíram de forma relevante no cálculo estratégico dos atores envolvidos advogados de defesa e investigados/acusados - quanto à conveniência de celebração da colaboração premiada. Se considerarmos, como foi exposto nas seções anteriores deste artigo, que a decisão do HC2 representou alto grau de ativismo da Corte, é razoável afirmar que isto se deu para agregar um elemento chave à engenharia da operação, sem o qual ela não alcançaria a mesma efetividade. Em outras palavras, trata-se de um tipo especial de ativismo, aquele que visa a (re)modelagem institucional.

\section{CONCLUSÃo}

Este artigo buscou, mais do que extrair a ratio decidendi da decisão do STF que mudou a concepção do princípio da presunção de inocência, identificar elementos internos e externos aos julgamentos, os quais, tomados conjuntamente, sugerem a intenção da Corte de interferir na administração do sistema prisional, no primeiro caso, e nos rumos e resultados da operação Lava Jato, no segundo.

Especialmente no HC2, os elementos que indicam essa ação direcionada do STF podem ser assim sintetizados. Em primeiro lugar, foi notável o exercício do poder de agenda para pautar o julgamento do habeas corpus quando não havia justificativa para urgência na apreciação da matéria (acusado em liberdade e inexistência de risco de prescrição). Em segundo, o momento escolhido (agenda) pelo ministro Teori Zavascki para submeter o julgamento ao plenário se deu em meio a intenso acompanhamento da mídia e da sociedade civil sobre os desdobramentos da Lava Jato, e seguramente não foi mera coincidência que a iniciativa de pautá-lo tenha sido obra do mesmo ministro responsável pelas ações penais originárias da Lava Jato em trâmite no STF. A ausência de prévios debates que indicassem um possível processo de amadurecimento a exigir novo pronunciamento sobre o tema, bem como a ausência de discussão sobre o artigo 283 do Código de Processo Penal e o fato de que o próprio Ministério Público manifestou-se a favor da manutenção do antigo posicionamento da Corte são sinais de que o tribunal mergulhou em franco ativismo.

O índice médio de punitivismo nos casos de $\mathrm{HC}$, calculado a partir dos dados de Duarte e Martins (2019), como se viu, vinha diminuindo nos anos anteriores e nada indicava uma mudança tão brusca de direção como a que se deu com o HC2. Pelo contrário, vimos como o tribunal vinha se engajando fortemente numa "agenda do sistema penitenciário", tangenciando posições libertárias e forçando políticas de desencarceramento. Até mesmo o volume de recursos extraordinários distribuídos no STF, que teve diminuição desde o julgamento do habeas corpus paradigma da mudança, indica que o posicionamento anterior não redundara em 
aumento do uso desta modalidade recursal. Por fim, mas não menos importante, a comparação de argumentos voltados à ratio decidendi em cada caso mostrou como houve um deslocamento importante do debate baseado em dispositivos e princípios constitucionais (HC1) para questões práticas e institucionais, especialmente as relativas à efetividade do sistema penal (HC2).

A análise comparativa dos dois HCs mostra que, mesmo se tratando de casos concretos, o STF varia a forma de enquadrá-los, recorre a fontes jurisprudenciais distintas e produz conclusões que afetarão diferentes dimensões da aplicação do direito. Essa dinâmica torna a jurisprudência do tribunal um tanto gelatinosa, mas mantém alternativas permanentemente abertas caso a Corte queira reverter no futuro suas decisões presentes, com custos menores do que naqueles que incorreria se estivesse revendo uma jurisprudência consolidada. Assim, se no primeiro HC a presunção de inocência teve um papel central na decisão, no segundo HC o tribunal não precisou reformular sua interpretação constitucional daquele princípio, já que elegeu outro repertório para tomar a decisão e estabelecer um novo parâmetro para a execução penal. Desse modo, o princípio da presunção de inocência continuou em grande medida intacto, e o tribunal pôde voltar a ele no julgamento de mérito das ADCs 43, 44 e 54, modificando pela terceira vez no período o seu entendimento sobre a matéria. ${ }^{26}$

Essa maleabilidade na forma de decidir do STF não explica, todavia, porque os ministros resolveram inovar e estabelecer a necessidade de cumprimento da pena a partir da sentença de segundo grau. A maleabilidade é uma condição necessária, mas não suficiente para a explicação. $O$ que este trabalho demonstra é que o contraste entre os julgamentos do primeiro e do segundo HC talvez seja apenas aparente: a redução das oportunidades de protelação do cumprimento da pena não agravará a situação da população carcerária de baixa renda, mas apenas daqueles que dispõem de recursos para esticar o processo ao longo das instâncias judiciais. Digamos que o problema daquela imensa população carcerária, pobre e desassistida, é que sequer foi julgada em primeiro grau e encontra-se presa de modo provisório ou mesmo ilegal. Assim, faz sentido separar as duas decisões e não as tomar como contraditórias necessariamente. Se este raciocínio está correto, então a motivação do julgamento do segundo HC não reside numa mudança de

\footnotetext{
${ }^{26}$ Este artigo foi concluído antes do julgamento das ADCs 43, 44 e 54 que, em novembro de 2019, levou o STF a modificar novamente sua posição sobre o tema. Não cabe neste espaço esquadrinhar a decisão e os votos dos ministros que, por $6 \times 5$, passaram a afirmar a presunção de inocência e suspenderam a execução provisória da pena após condenação em segunda instância. Um exame da forma como a presidência do tribunal exerceu o poder de agenda em relação às ADCs, o impacto do contexto (marcado pela decadência da Lava Jato, após os vazamentos de conversas de seus principais operadores, revelando os métodos questionáveis por eles utilizados durante a operação) os tipos de argumentos mobilizados pelos ministros e a forma como lidaram com a jurisprudência da corte permitiria colocar esse julgamento em linha com os dois anteriores, reforçando a tese do presente artigo acerca da ação estratégica e do "ativismo de modelagem institucional" do STF.
} 
paradigma em relação ao primeiro, mas nas outras hipóteses desenvolvidas neste artigo, sob a ótica da ação estratégica do tribunal: 1) a de que o alvo da mudança estava nos criminosos de colarinho branco e da classe política, no contexto maior da Lava Jato e sob forte pressão da opinião pública, 2) a de que a reforma da jurisdição penal pelo HC2 redesenharia o sistema de justiça criminal, otimizando o trabalho das instâncias inferiores e reservando ao próprio STF a condição de foro especial em cenário de grande aumento do número de ações penais levadas à corte.

Enquanto a judicialização da política em geral é vista como decorrência do desenho institucional, o caso aqui examinado revela o inverso, isto é, quando tribunais operam o poder de agenda e mergulham em ativismo judicial para alterar as regras institucionais, afetando assim o comportamento de outros atores e instituições. ${ }^{27}$ Uma ação estratégica deste tipo poderia tornar desnecessário ou irrelevante o exame dos votos dos ministros, porque neles não encontraríamos uma ratio decidendi genuinamente forjada a partir de preferências sinceras. Todavia, a comparação das decisões do HC1 e HC2 permitiu verificar que argumentação e justificação constituem tarefas inescapáveis aos ministros e a análise dos dois casos ajudou a elucidar a direção almejada pela ação estratégica da Corte.

$\mathrm{O}$ ativismo judicial da corte representado nestes dois casos expressa bem elementos dos cinco tipos descritos por Kmiec (2004) vistos no início deste artigo. O STF usou seu poder de judicial review para investir contra princípios indiscutivelmente constitucionais como a presunção de inocência e a prisão após trânsito em julgado. Rompeu horizontalmente com seus próprios precedentes, em curto espaço de tempo e mediante argumentos distintos em cada caso. Ultrapassaram até mesmo a hipótese de judicial legislation, uma vez que não introduziram norma onde não havia, mas passaram por cima do novo art. 283 do CPP, contrariando a vontade expressa do legislador. Embora nao tenha sido possível examinar aqui os diferentes métodos de interpretação utilizados pelos diferentes ministros, a análise dos votos mostrou grande variação de argumentos, nos quais muitas vezes o direito figurou como mera racionalização do resultado que se queria alcançar. Ao produzirem resultados distintos, críticas de ativismo judicial podem ser desferidas contra essas abordagens. Por fim, restaria saber se especialmente o HC2 conteve o "scienter element", isto é, a adoção de um ponto de partida consciente e deliberadamente irregular por parte dos ministros que formaram maioria, mas que lhes permitiu produzir o resultado almejado (Kmiec 2004, p. 1475). Deixamos ao leitor e ao futuro a confirmação dessa última hipótese.

${ }^{27}$ Talvez o argumento desenvolvido neste texto guarde relação com a hipótese desenvolvida por Desposato, Ingram e Lannes (2014), a de que os ministros do STF acentuaram seu comportamento atitudinal após a reforma do judiciário, que fortaleceu o STF. Em outras palavras, a mudança de composição do tribunal neste período foi algo importante, mas somada a essa mudança o fortalecimento institucional do Supremo encorajou seus ministros ao policy making. 
Em conclusão, num cenário de forte instabilidade política e institucional como o nosso, compreender como e porque o STF se mostra ativista e decide estrategicamente é de extrema importância. De fato, na quadra que se inicia em 2014 o tribunal já se envolveu em diversas situações críticas e há bons indícios de que algumas de suas decisões tiveram igualmente caráter estratégico. Se o contexto impôs essa necessidade à Corte, por outro lado seu capital político sofreu significativa deterioração e no acerto de contas não resta claro qual é o saldo de sua atuação frente à travessia pela qual passa a democracia brasileira. Embora a análise desenvolvida neste artigo não constitua exatamente um modelo que possa ser replicado em outros casos, esperamos ter dado um passo nessa direção, contribuindo para o estudo do ativismo de modelagem institucional praticado pelo STF, muito frequente em outras tantas decisões da corte.

\section{REFERÊNCIAS}

AMARAL, Thiago Bottino. Habeas corpus nos Tribunais Superiores: uma análise e proposta de reflexão. Rio de Janeiro: Fundação Getúlio Vargas, 2016.

ARANTES, Rogério Bastos. The Federal Police and the Ministério Público. In: POWER, Timothy; TAYLOR, Matthew. (Org.). Corruption and Democracy in Brazil. Notre Dame: University of Notre Dame Press, 2011 (2011a).

ARANTES, Rogério Bastos. Polícia Federal e Construção Institucional. In: AVRITZER, Leonardo; FILGUEIRAS, Fernando (Orgs.). Corrupção e Sistema Político no Brasil. Rio de Janeiro: Civilização Brasileira, 2011 (2011b).

ARANTES, Rogério Bastos. Judiciário: entre a Justiça e a Política. In: AVELAR, Lúcia; CINTRA, Antônio Octávio (Orgs.). Sistema Político Brasileiro: uma introdução. 3. ed. São Paulo: Editora Unesp, 2015.

ARANTES, Rogério Bastos et al. Controles democráticos sobre a administração pública no Brasil: Legislativo, tribunais de contas, Judiciário e Ministério Público. In: LOUREIRO, Maria Rita Loureiro; ABRUCIO, Fernando Luiz; PACHECO, Regina Silvia (Orgs.). Burocracia e política no Brasil: desafios para o Estado democrático no século XXI. Rio de Janeiro: Editora FGV, 2010.

ARANTES, Rogério; ARGUELHES, Diego Werneck. O estado da arte da pesquisa sobre o Supremo Tribunal Federal. In: FEFERBAUM, Marina; QUEIROZ, Rafael 
Mafei R. Metodologia da pesquisa em Direito. Técnicas e abordagens para a elaboração de monografias, dissertações e teses. São Paulo, Saraiva, 2019.

ARGUELHES, Diego Werneck; RIBEIRO, Leandro Molhano. Ministrocracia: O Supremo Tribunal individual e o processo democrático brasileiro. Novos estudos CEBRAP, v. 37, n. 1, 2018, p. 13-32.

BRASIL. Senado Federal. Proposta de Emenda à Constituição n 15, de 2011 (PEC DOS RECURSOS). 2011 (2011a). Disponível em:

$<$ https://www25.senado.leg.br/web/ atividade/materias/-/materia/99758>. Acesso em: 13 set. 2019.

BRASIL. Supremo Tribunal Federal. Somente condenações definitivas podem gerar inelegibilidade de candidatos (ementa da ADPF 144). Notícias, 20 out. 2009 (2009a). Disponível em:

<http://www.stf.jus.br/portal/cms/verNoticiaDetalhe.asp?id Conteudo=115003>. Acesso em: 08 jun. 2016.

BRASIL. Supremo Tribunal Federal. Habeas Corpus no 84.078, inteiro teor do acórdão. Brasília, DF, 05 de fevereiro de 2009 (2009b). Diário de Justiça no 35 do dia 26 de fevereiro de 2010.

BRASIL. Supremo Tribunal Federal. "PEC dos Recursos" é apresentada pelo presidente do STF e estará no III Pacto Republicano. 2011 (2011b). Disponível em: $<$ http://www.stf.jus.br/portal/cms/verNoticiaDetalhe.asp?idConteudo=174751>. Acesso em: 13 set. 2019.

BRASIL. Supremo Tribunal Federal. Habeas Corpus no 126.292, inteiro teor do acórdão. Brasília, DF, 17 de fevereiro de 2016. Diário de Justiça no 100 do dia 17 de maio de 2016.

BRASIL. Supremo Tribunal Federal. Recurso Extraordinário no 580.252, inteiro teor do acórdão. Brasília, DF, 16 de fevereiro de 2017. Diário de Justiça nº 204 do dia 11 de setembro de 2017.

BRASIL. TRF4. Lava Jato: 645 processos em três anos no TRF4. 2017. Disponível: $<$ http://www2.trf4.jus.br/trf4/controlador.php?acao=noticia_visualizar\&id_noticia $=12712>$. Acesso em: 30 maio 2017. 
DESPOSATO; Scott; INGRAM; Matthew LANNES, Osmar. Power, Composition, and Decision Making: the Behavioral Consequences of Institutional Reform on Brazil's Supremo Tribunal Federal. Journal of Law, Economics, and Organization, v. 31, n. 3, 2014.

DUARTE, Guilherme; MARTINS, Rodrigo. The Brazilian Supreme Court and the atitudinal model: evidence from Habeas Corpus decisions. $2^{\circ}$ Workshop Mare Incognitum: desafios da pesquisa empírica sobre o Supremo Tribunal Federal. FGV-RJ, 13 e 14 de setembro de 2018.

FALCÃO, Joaquim; ARGUELHES, Diego Werneck. Onze Supremos: todos contra o plenário. In: FALCÃO, Joaquim; ARGUELHES, Diego Werneck; RECONDO, Felipe (Orgs.). Onze Supremos: O Supremo em 2016. Belo Horizonte: Letramento/Casa do Direito/Jota/FGV Direito Rio, 2017, p. 20-28.

FALCÃO, Joaquim; HARTMANN, Ivar A.; CHAVES, Vitor P, III Relatório Supremo em Números: O Supremo e o tempo. Rio de Janeiro: Escola de Direito do Rio de Janeiro da Fundação Getúlio Vargas, 2014. Disponível em: <http://www.fgv.br/supremoemnumeros/publicacoes.html>. Acesso em: 22 maio 2017.

FOLHA DE SÃO PAULO. Grupo de juízes auxilia STF no julgamento do mensalão. 2012. Disponível em: <http://www1.folha.uol.com.br/fsp/poder/51967grupo-de-juizes-auxilia-stf-no-julgamento-do-mensalao.shtml>. Acesso em: 15 mar. 2018.

KMIEC, Keenan D. The Origin and Current Meanings of Judicial Activism. California Law Review, v. 92, n. 5, 2004, p. 1441-1477.

MORO, Sérgio Fernando. Considerações sobre a Operação Mani Pulite. Revista CEJ, Brasília, n. 26, p. 56-62, jul./set 2004. Disponível em: $<$ https://www.conjur.com.br/dl/artigo-moro-mani-pulite.pdf >. Acesso em: 01 mar. 2020.

O GLOBO. Delações em série: com 12 acordos fechados, Lava-Jato tem colaboração recorde. 2014. Disponível em: <https://oglobo.globo.com/brasil/ delacoes-em-serie-com-12-acordos-fechados-lava-jato-tem-colaboracao-recorde14888671>. Acesso em: 13 jun. 2017. 
O GLOBO. Gilmar Mendes reclama de decisão do juiz e manda soltar pela segunda vez Daniel Dantas. 2008. Disponível em:

$<$ https://oglobo.globo.com/economia/gilmar-mendes-reclama-de-decisao-do-juizmanda-soltar-pela-segunda-vez-daniel-dantas-3609178>. Acesso em 11 set. 2019.

RIBEIRO, Leandro; ARGUELHES, Diego W. Preferências, Estratégias e Motivações: Pressupostos institucionais de teorias sobre comportamento judicial e sua transposição para o caso brasileiro. Revista Direito e Práxis, v. 4, n. 7, 2013, p. 85-121.

SILVA, Virgílio Afonso da. O STF e o controle de constitucionalidade: deliberação, diálogo e razão pública. Revista de Direito Administrativo, n. 250, 2009, p. 197-227.

TATE, C. Neal; VALLINDER, Torbjörn. The Global Expansion of Judicial Power: The Judicialization of Politics. In: TATE, C. Neal; VALLINDER, Torbjörn (Eds.). The Global Expansion of Judicial Power. New York: New York University Press, 1995, p. 01-10.

TATE, C. Neal. Why the Expansion of Judicial Power? In: TATE, C. Neal; VALLINDER, Torbjörn (Eds.). The Global Expansion of Judicial Power. New York: New York University Press, 1995, p. 27-37.

UOL. Política. Delações e ajuda internacional explicam sucesso da Lava Jato, diz ONU. 2016. Disponível em: <https://noticias.uol.com.br/politica/ultimasnoticias/2016/01/11/delacoes-e-ajuda-internacional-explicam-sucesso-da-lava-jatodiz-onu.htm>. Acesso em: 13 jun.2017.

VALLINDER, Torbjörn. When the Courts Go Marching, In: TATE, C. Neal; VALLINDER, Torbjörn (Eds.). The Global Expansion of Judicial Power. New York: New York University Press, 1995, p. 13-26.

VIEIRA, Oscar Vilhena. Supremocracia, Revista Direito GV, v. 4, n. 2, 2008, p. 441-464.

VOJVODC, Adriana de Moraes; MACHADO, Ana Maria França; CARDOSO, Evorah Lusci. Escrevendo um romance, primeiro capítulo: precedentes e processo decisório no STF. Revista Direito GV, v. 5, n. 1, 2009, p. 21-44. 